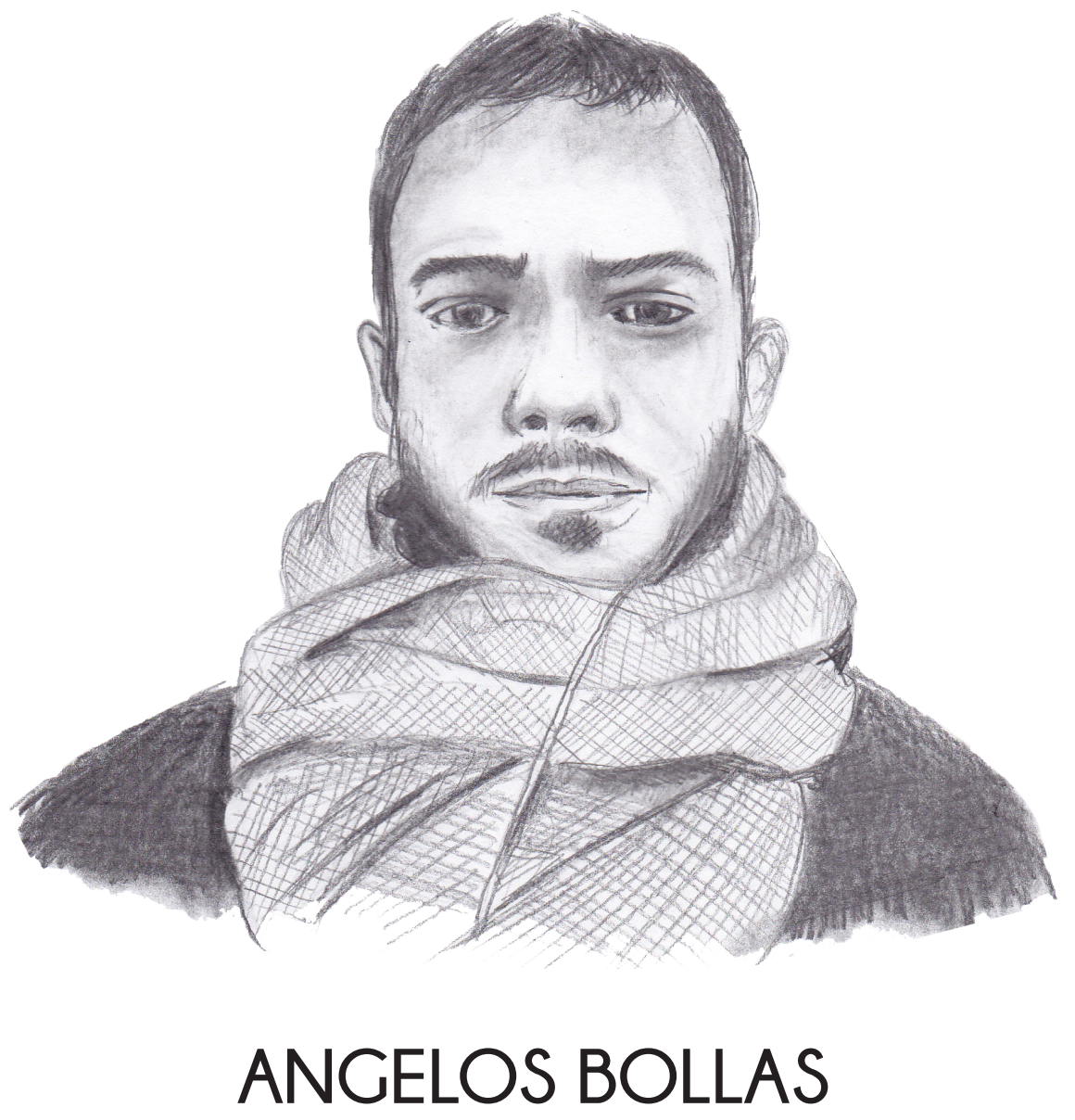

Angelos Bollas is a senior studying English at DEREE - The American College of Greece. A believer of the proverb "There's nowt so queer as folk," Angelos's interests lie on the study of humans and of narrative representations of erotic desire between men. His current research is focused on the way in which literary and/or theatrical form is crafted so as to (re)create social meaning and invoke social change. 
FORBES \& FIFTH

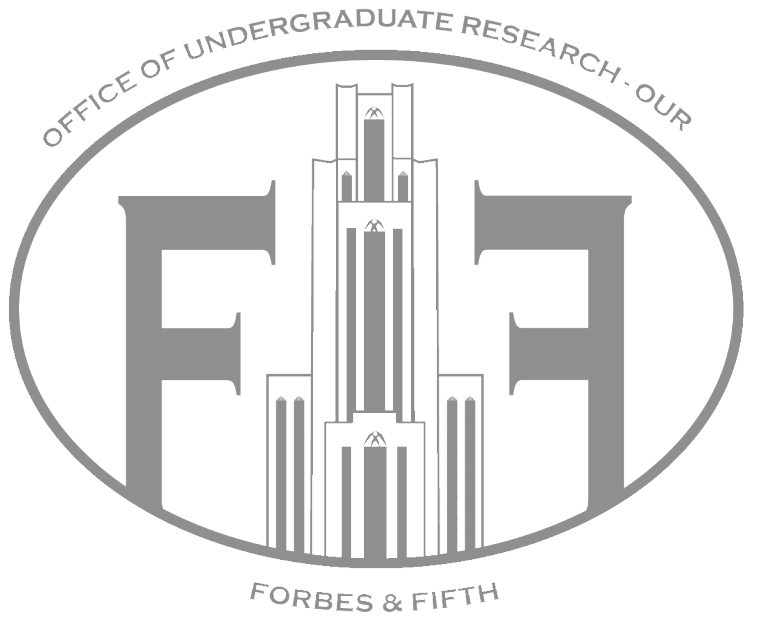




\section{"Live and Let Live": The Destabilization of Heteronormativity in Moisés Kaufmann's "The Laramie Project"}

Moisés Kaufmann's "The Laramie Project," dramatizes the aftermath of university student Matthew Shepard's murder by focusing on the reactions of the citizens of Laramie, Wyoming, to the murder's representation by the media. The media presents Laramie as a typical Midwestern American town where cowboys, violence, and brutality constitute its daily routine. Apart from the focus on media influence, "The Laramie Project" offers insight into the heteronormative mindset of Laramie, Wyoming. Critical responses to the play have largely focused on the social implications of Shepard's murder, possible causes, lack of special legislation, and the depiction of Midwestern American society; yet, none of them have focused on the heteronormative net within which society has been rooted. Kaufmann's play does not attack Laramie for being reactionary. It rather exposes and questions the construction of the residents" mindsets that led two of "their own" to commit such a brutal crime. Through the use of documentary theater devices - namely, selection and arrangement of interview material - Kaufmann reveals the irony behind the "live and let live" motto and the dominance of a heteronormative mindset which names non-exclusive desire for the opposite sex "deviant." Kaufmann also exposes the irony behind the "live and let live" philosophy which allows Laramie residents consider tolerance and acceptance indistinguishable.

Critics such as Eve Kosofsky Sedgwick, Elizabeth Atkinson, Renee DePalma, and Samuel Chambers follow Judith Butler's theory on the heteronormative matrix, arguing that heteronormativity is a political net upon which society sustains its maintenance. Some of these critics connect heteronormativity to feminism and patriarchy, while others connect it to social class. "The Laramie Project", though, manifests the dominance of heteronormativity upon the whole of society regardless of sexual orientation, gender, or social status. However, because society tends to be more accepting of women who desire other women, heteronormativity "attacks" males rather than females. In Between Men English Literature and Male Homosocial Desire, Eve Sedgwick explains how society's reaction to male intimacy, even historically, is dif- 
ferent and less flexible than the reception of females who are attracted to other females. ${ }^{1}$ Thus, the application of heteronormativity as a social force which shapes human thoughts and actions almost exclusively affects males rather than females who are attracted to the same sex.

Aligned to the polemics of the genre, Kaufmann, in "The Laramie Project," destabilizes heteronormativity through the ironic juxtaposition of the discourses of males who either approve of sexual desire for the same sex or are attracted to people of the same sex themselves to those who regard these behaviors as deviant; moreover, his ironic arrangement and titles of the moments that contain these discussions highlight the illusion of "tolerance and acceptance" and reinforce the destabilization of heteronormativity.

Kaufmann offers a broad variety of male perspectives on same sex attraction: the juxtaposition which highlights the effects of heteronormativity on people's attitudes since they, regardless of sexual orientation, treat "such" behaviors as abnormal. The dominant institutions, views on which inform the play immensely, are religion and family. The discourses of their representatives in the play offer extreme views on "deviant" sexual behaviors. They also hint at the irony of the "live and let live" philosophy that enforces the "us versus them" notion prevailing Laramie and stresses the hatred for difference with which Laramie residents are raised.

The most extreme view against people who practice same sex relationships is offered by Reverend Fred Phelps who, though not a Laramie resident, camps out at the site of Matthew's vigil:

"[...] But this murder is different, because the fags are bringin' us out here trying to make Matthew Shepard into a poster boy for the gay lifestyle. And we're going to answer it. [...] Because God's hatred is pure. It's a determination that he's gonna send some people to hell. [...] Is homosexuality - is being a fag okay? What do you mean it's not for you to judge? If God doesn't hate fags, why does he put 'em in hell? [...] You see the barrenness and sterility of your silly arguments when set over against some solid gospel truth? Barren and sterile. Like your lifestyle."

Shepard is further victimized in death through Reverend Phelps' use of 
derogatory language. Phelps, an outsider, takes advantage of the incident in order to voice his beliefs; however, leaders of Laramie's churches hold the same attitude. Murdock Cooper, a fifty-year-old rancher, when reflecting on the connection between Shepard's sexual orientation and his murder, says, "It doesn't bother anybody because most of 'em that are gay or lesbian they know damn well who to talk to. If you step out of line you're asking for it. [...] You don't pick up regular people." 3 Cooper accuses Shepard, and others attracted to people of the same sex, of being

"Cooper accuses Shepard, and others attracted to people of the same sex, of being responsible for their own brutal beatings and murders, thus implying that being gay provokes violence." responsible for their own brutal beatings and murders, thus implying that being gay provokes violence. He labels them as being "irregular," enforcing the "us versus them" notion that prevails in Laramie. Simultaneously, though, Cooper's words illustrate the illusions of the residents who believe the "live and let live" proverb. Cooper actually says that "regular people" do not care about "gay or lesbian" people as long as the latter do not contact the former. Thus the "live and let live" philosophy becomes a "don't ask, don't tell" philosophy which dictates that people who are attracted to others of the same sex should stay in the closet.

Heteronormativity has blurred the notions of tolerance and acceptance in the residents' minds. Doug Laws, the Stake Ecclesiastical leader for the Mormon Church in Laramie, in his attempt to offer his church's stance on the topic, explains that "there's no sexual deviation in the Mormon Church," because they are focused on the institution of the family that consists of "one woman and one man and children," and any leniency is neither accepted nor tolerated. ${ }^{4}$ The Baptist minister's wife says that although her husband is against the murder, he is against "that kind of lifestyle," as well. ${ }^{5}$ When the Baptist minister himself is asked to comment on Shepard's murder, he says:

"That lifestyle is legal, but I will tell you one thing: I hope that Matthew Shepard as he was tied to that fence, that he had time to reflect on a moment when someone had spoken the word of the Lord to him - and that before he slipped into a 
coma he had a chance to reflect on his lifestyle."6

The Baptist minister accuses Shepard of being a sinner simply because of his sexual orientation, as though he provoked his own murder. His view shows the way in which people of Laramie have been raised and how religion enforces the concept of heteronormativity in such a conservative way.

Family as an institution raises children with the same ideology. When Jedadiah Schultz, a nineteen-year-old university student, invites his parents to the performance of a scene from "Angels in America" he was to perform in order to get the scholarship for the theater department in the University of Wyoming, they tell him that if he does the scene, they will not watch him "because they believ[e] that it is wrong - that homosexuality is wrong." Schultz, however, cannot feel anger towards his parents, because he himself believes that "homosexuality is wrong." " He does not react to their refusal to see him - he did the scene and won the scholarship - but when he reflected on his disobedience, he said: "Thinking back on it, I think, why did I do it? Why did I oppose my parents? 'Cause I'm not gay. So why did I do it?" Schultz's words reveal his perception of people who desire people of the same sex as being disobedient and rebellious. Later in the play, when Conrad Miller, a thirty-year-old car mechanic, is asked about his stance towards same sex relationships, he says:

"And if my kids asked me, I'd set them down and I'd say,
'Well, this is what gay people do. This is what animals do.
Okay?' And I'd tell 'em, 'This is the life, this is the lifestyle,
this is what they do.' And I'd say, 'This is why I believe it's
wrong."'

Conrad Miller's terrifying statement informs the readers/audience about the way his children will be raised, perceiving same sex relationships not only as deviant but also as animalistic.

The discourses of the religious leaders along with Conrad Miller's way of nourishing his children offer the readers/audiences an answer to the question of the motives of the perpetrators. The narrative shows that people are raised in such a way that allows space for a hetero- 
normative mindset to flourish. Extreme views on the topic do not come only from religion and family, but Kaufmann chooses to include other voices shaped by heteronormativity, since both religion and family have cultivated them. For instance, when tapping into the theme of the reception of Shepard's murder, most of the characters argue that it will give others who desire people of the same sex the chance to raise their voice and protest for rights that they should not claim. Governor Geringer "urge[s] the people of Wyoming against overreacting in a way that gives one group "special rights over others," 10 while Gil Engen, a fifty-yearold rancher "think[s] that the gay community took this as an advantage, said this is a good time for [them] to exploit this." "Rulon Stacey, CEO Poudre Valley Hospital in Fort Collins, informs us about letters that he

"Rulon Stacey, CEO Poudre Valley Hospital in Fort Collins, informs us about letters that he received after crying in public while announcing Shepard's death. One of them read, 'Do you cry like a baby on TV for all of your patients or just for the faggots?'” received after crying in public while announcing Shepard's death. One of them read, "Do you cry like a baby on TV for all of your patients or just for the faggots?"12 The letter suggests that what is defined as homophobia is part of the fabric of American society. Institutions such as family and religion that teach the word of the Lord to young people are often shaped by heteronormativity in an attempt to be self-sustained. Such a notion transcends the following generations, adding to the hate that divides people according to their distance from the norm.

Ironically, Kaufmann allows voices of people who claim to be tolerant towards same sex relationships to be heard. However, they too are influenced by heteronormativity since they continue to label "such" behaviors and regard them as unequal and less deserving of respect. Sergeant Hing, a detective at the Laramie Police Department, articulates Laramie's mentality: "We have one of the most vocal populations of gay people in the state... and it's pretty much 'live and let live." ${ }^{13}$ In the course of the play, this mentality is undermined by the discourse and words used by the residents. Doc O'Connor's description of Shepard as "maybe gay but straightforward," 14 or Phil Labrie's comment, "the fact that he was at the bar alone without any friends made him that much more vulnerable," ${ }^{15}$ illustrate this fact. O'Connor, a limousine driver 
who offers Shepard many lifts, is impressed by him because, contrary to the stereotype of people who are attracted to people of the same sex being rude and evasive, he acts like a "normal" person who happens to desire others of the same sex. Labrie, a close friend of Shepard's, implies that the sexual orientation of his friend made him vulnerable by definition and that others should always accompany him for protection. Beth Loffreda's Losing Matt Shepard: Life and Politics in the Aftermath of Anti-gay Murder examines the life of people that commit same sex relationships in the context of Laramie, Wyoming. Loffreda argues that in Laramie, Wyoming there is nothing like coming out of the closet because there is very little to go out of it. ${ }^{16}$ Some of her personal interviews support Kaufmann's depiction of Laramie as a place where heteronormativity guides people's attitudes. When analyzing the influence of heteronormativity on those who are not declaring against those of "deviant" sexual orientation, Loffreda comes to the conclusion that "it is expressions of affection, not sex, that strike them as most threatening to whatever harsh codes of masculinity." ${ }^{17}$ That is, people who tend to be "more tolerant" are still not willing to understand behaviors that do not align to the norm as equal to theirs. When she asked a young Laramie resident what he thought of the perpetrators, he said, "Those guys are assholes, beating on someone so small." When he was asked if he would have done the same if someone approached him, he said that he wouldn't if he was as small as Shepard. Loffreda insisted, "What if he were bigger than you?" The young man hesitated for a moment and answered, "Well, I guess I wouldn't hit him either."18 A few months after Shepard's brutal murder, there are still young people who would possibly do the same under the same circumstances. Opposing Hing's description of Laramie as "one of the most vocal populations of gay people in the state," Stephanie, one of Loffreda's interviewees, says: "If there is anything like a gay and lesbian community in Laramie, it's a community that does not have a big social presence and does not have much of an awareness of itself as a defined entity." ${ }^{19}$ Stephanie's comment, in contrast to Hing's, shows that people in Laramie are happy to have a "diverse community" so long as it remains silent.

Marginalized voices of those people attracted to the same sex could not have been missing in "The Laramie Project." These voices enforce Kaufmann's irony since, as with the previous ones, they are 
influenced by heteronormativity themselves. Jonas Slonaker, a fortyyear-old man, says that his friends do subscribe to the "live and let live" ideology:

"[...] Live and let live. That is such crap. I tell my friends that - even my gay friends bring it up sometimes. I'm like, 'That is crap, you know?' I mean basically what it boils down to: If I don't tell you I'm a fag, you won't beat the crap out of me. I mean, what's so great about that? That's a great philosophy?"20

However, while accounting his experiences about others who consider Laramie as " "not a place where [they] can live," 21 he keeps saying that sexual orientation should not make anyone leave their towns. In his speech, though, he keeps labeling himself and others as "gay." Thus, while trying to be inclusive, he excludes himself from the society he wants to be a part of by using names that limit his identity. Later in the play, Father Roger Schmit, focuses on the power of language and Kaufmann uses his words to show that heteronormativity has even shaped language:

\footnotetext{
"You think violence is what they did to Matthew - they did do violence to Matthew - but you know, every time that you are called a fag, or you are called a you know, a lez or [...] a dyke. Do you realize that this is violence? That is the seed of violence." ${ }^{22}$
}

According to Father Roger Schmit, Slonaker performs violence on himself constantly by labeling both himself and others. Martin Kantor, author of Homophobia in Gays and Lesbians argues that "self-homophobia in gays and lesbians can be just as much a symptom of emotional disorder as homophobia in straights directed toward gays and lesbians." ${ }^{23}$ Kantor analyzes the implications of heteronormativity on its victims. Slonaker's discourse, quoted above, is affected by the notion of heteronormativity in such a degree that he himself considers being unequal, special, less respectful, and subject of rejection. Slonaker is victimized by the heteronormative net upon which social institutions have been founded. Elizabeth Atkinson's and Renee DePalma's argument that But- 
ler's concept that the "heterosexual matrix is sustained by belief," along with their conclusion that to ameliorate heteronormativity, instead of opposing the old and proposing a new heterosexual matrix, we should disorganize and deconstruct the already existing one, ${ }^{24}$ falls apart when statements like Slonaker's ones are articulated. Slonaker has not accepted the heterosexual matrix. Slonaker has been raised in heteronormativity, believing that being attracted to people of the same sex is deviant and should

"You think violence is what they did to Matthew - they did do violence to Matthew - but you know, every time that you are called a fag, or you are called a you know, a lez or [...] a dyke. Do you realize that this is violence? That is the seed of violence."' be excluding as such. Heteronormativity, thus, presents society as being comprised of two homocentric cycles, the smaller one embedded to the bigger one, dictating that not residing in the territory of the small cycle would lead to one's ostracism. If the juxtaposition of these three different discourses hadn't happened onstage, then Kaufmann wouldn't have stressed the effects of heteronormativity in society.

Kaufmann becomes more provocative against heteronormativity by manipulating the play's form to create meaning. The ironic arrangement and titles of moments in "The Laramie Project" allows readers/ audiences to unfold the society of Laramie, observe its hypocrisy, and identify with the author's attempt to destabilize heteronormativity as a dominant trait of Laramie, Wyoming. The author, in his essay "Into the West: An Exploration in Form," presents the relationship between content and form, and shows how readers'/audiences' reactions to both creates meaning. ${ }^{25}$

Rich Brown, in his paper "Moisés Kaufmann: The Copulation of Form and Content," investigates the creation of meaning through Kaufmann's moments. Brown's arguments are performance oriented and give particular attention to the staging of the moments and their effect. Specifically, he focuses on the effects of the juxtaposition among various moments to the audience. "The positioning of the Moments creates meaning through context," Brown says, "just as the contextualization of content in relation to its form creates meaning within each individual Moment. Form and content copulate through contextualization. ${ }^{26}$ In the very beginning of the play, Rebecca Hilliker's moment, Rebecca 
Hilliker, expresses the satisfaction that various Laramie voices will be heard, and suggests Jedadiah Schultz, as a student, must be heard. This prepares the readers/audience to expect comments that are not against Shepard or his sexual orientation. Contrary to that, Schultz's moment in Angels in America presents his and his parents' initial attitudes toward relationships between people of the same sex. Kaufmann, here, apart from presenting the hypocrisy of the Laramie society, chooses to enforce this realization by contrasting the expectations of the audience/readers to the actual moments that follow through the juxtaposition of specific moments.

Jay Baglia and Elissa Foster, in "Performing the "Really" Real: Cultural Criticism, Representation, and Commodification in The Laramie Project" offer us accounts of their experiences as members of "The Laramie Project" audience. Although their essay is primarily concerned with reception theory, the authors provide commentary on the effects of Kaufmann's moment work and, specifically, how their juxtaposition affects meanings. ${ }^{27}$ Being members of the audience on various performances, Baglia and Foster acknowledge the importance of the juxtaposition, concluding that Kaufmann's intention would have been lost having not experimented with the form. In a later part of the play, Kaufmann's experimentation with form allows him to stress the hypocrisy of religion that seems not to be tolerant of more "different lifestyles" than the ones they preach to be. Between the moments The Word and Lifestyle 1, which expose the religious views on the murder and "lifestyle" of those who are not following the typical family ideal "one man, one woman, and children," ${ }^{28}$ Kaufmann inserts a short moment called A Scarf in which the experiences of Zubaida Ula, an Islamic feminist, are narrated, highlighting the difficulties of being different in Laramie. Initially, The World and the Lifestyle 1 moments intend to express the religious views that accept every different person but those who do not follow the family ideal. The insertion of The Scarf moment, though, reveals the hypocrisy behind religion's claims, as they seem to accept only those who fill the norm.

Toward the end of the second act, Kaufmann literally bombards the audience with ironic understatements created by the juxtaposition of moments. After the medical update of Shepard's death, the moment Magnitude follows, creating feelings of disgust since it accounts peo- 
ple's negative reaction to the doctors' sensitive moment while announcing the death of Shepard. Yet, Kaufmann accentuates the irony by placing the $H-O-P-E$ moment that informs readers and audiences about Shepard's forgiving character after those two moments who, as Doc O'Connor narrates, "would not want [the perpetrators] to die. He'd want to leave them with hope." ${ }^{29}$ As readers or members of the audience, we are invited to identify the ones that were insulting the doctor for his sympathy to Shepard with the perpetrators, and at the same time to feel angry with them because we have just been informed about Shepard's death. Immediately after, we feel sorry for them because Shepard would have forgiven them. This procedure that we inevitably go through while experiencing the play exposes the hypocrisy of the Laramie society, and at the same time, elevates Shepard above it.

Kaufmann adds another element of irony: the juxtaposition between the titles and the content of the play. "Angels in America" is a title that suggests a content in support of people who are attracted to people of the same sex. However, under this title one finds Schultz's narration offered above. In the second act, there is one moment titled One of Ours. Similarly, one expects to read about the fact that a local young boy was murdered because of his sexual orientation. However, under this title, Sherry Johnson's speech is found. Johnson tells the members of the Tectonic Theater Group that she is upset because one police officer died due to an accident, and it did not became first page in the news while someone that could be "spreading AIDS and a few other things" is instead focused upon. ${ }^{30}$

Leopold Lippert, in "Life in the Memory of One Who No Longer Lives," examines the structure of "The Laramie Project." The work, against the politics of futurity, argues that Kaufmann suggests a future where tolerance will be replaced by acceptance. ${ }^{31}$ Indeed, Jedadiah Schultz's character is definitely used for this matter. Schultz, apart from his first moment where he articulated his negative attitude towards people who shared "Shepard's lifestyle," appears three times again. In the last one, Schultz says:

"I just feel bad. Just for all that stuff I told you, for the person I used to be. That's why I want to hear those interviews from last year when I said that stuff. I don't know. I just can't 
believe I ever said that stuff about homosexuals, you know. How did I ever let that stuff make me think that you were different from me?"32

Kaufmann's manipulation of the play's form allows the readers and the audiences of "The Laramie Project" to feel angry, sorry, and hopeful about the society in which they belong. They are expected to identify with the characters who are informed by heteronormativity, acquire a distance, and finally identify with Schultz who, having passed all of these stages himself, personifies Matt's H-O-P-E.

Kaufmann chooses to juxtapose different discourses in order to destabilize heteronormativity as the matrix upon which people and social institutions function. Yet, his experimentation of form and the appropriation of these discourses into the genre of the documentary theater allow him to become radical and caustic. He employs and manipulates the devices of the genre to achieve his goal, criticize society, and, at the same time, invite its members to change. Kaufmann interlaces content and form in order to critique a society which allows itself to be influenced by heteronormativity, and proposes a new one that will move from tolerance to acceptance. In Kaufmann's proposed society, the "live and let live" philosophy will be translated into "live together and next to one another."

\section{Appendix}

"The Laramie Project," as both an incident and play, aims to propose a society that will have time to reflect on itself and develop anew because of a tragic event. This new society is summarized in the following letter to the Wyoming Tribune-Eagle newspaper from two eighth grade students:

Some adults are not acting their age. We are appalled at the way people look at the gay community as something that is wrong and against God's will. If some of you people are Christian, we think you should already know God made human beings, and that he still loves every one of us no matter what our sexual orientation is. No matter what you are, we were all created equally, and 
we all deserve the same respect. People overlook the thoughts that go through kid's minds. A lot of people think that when we watch the TV, we watch cartoons and are couch potatoes, but some of us just happen to watch the news or read a newspaper article, and it gets us thinking about what is right and what is wrong about something. Some of the "so-called" adults who

"'We are two eighth grade students at McCormick Jr. High School, and every day we hear people being called gay. [...] Matthew was just another human being who was gay - so what, he still had all the human parts and breathed the same air and lived on the same planet. So, are you going to punish him for being human?'” do the protesting and make the bad comments about gays are acting more like children and less like their age, or are acting totally out of ignorance. We are two eighth grade students at McCormick Jr. High School, and every day we hear people being called gay. Yeah, so there might be some gay people at school, but some of us overlook that. We think that McKinney and Henderson should be punished for this terrible crime, and not Matthew Shepard. Matthew was just another human being who was gay - so what, he still had all the human parts and breathed the same air and lived on the same planet. So, are you going to punish him for being human? This has gone on for too long, and this terrible hate for another human has got to stop (Opinion, 10/23/1998). 
Bollas 
FORBES \& FIFTH 